\title{
Construction of business confidence index based on a system of economic indicators
}

\author{
Vita $\operatorname{Los}^{1, *}$, and Dmytro Ocheretin ${ }^{1}$ \\ ${ }^{1}$ Zaporizhzhia National University, Faculty of Economics, Zaporizhzhia, Ukraine
}

\begin{abstract}
One of the important indicators that characterize the economy of the country is the business confidence index. It is the basis for tracking the cycles of economic dynamics and analysis of the country's business climate. Evaluation of this indicator makes it possible to predict the crisis phenomena that are occurring in the economy, and to develop possible ways out of difficult situations. On the example of the five countries (Ukraine, Germany, Hungary, Slovenia, Poland) it was also analyzed the possibility of constructing the business confidence index based on economic indicators, which characterize current economic activity of the country. For analysis, the quarterly values of economic indicators over the last years were taken. The selected economic indicators based on cross-correlation analysis were ranked into three groups: coincident, lagging and leading indicators. Using coincident and leading economic indicators, the several regression models of the business confidence index were built. On the basis of the obtained regression models, the forecast of business confidence index value for the next period is evaluated and the trends of its development are established.
\end{abstract}

\section{Introduction}

The modern development of the domestic economy is characterized by deepening international economic relations in connection with the intensification of European integration processes. This is the reason for the new tasks that confront the national economy and require solution and coordination with the world methodology of business management. One such task is the assessment and analysis of the country's business climate. The indicator characterizing the business climate in European countries is the index of business expectations, or as it is called the business confidence index (BCI) [1]. The business confidence index is a special economic indicator that reflects the state of the economy as a whole and in its individual sectors. This index is especially important for macroeconomics, as it characterizes the efficiency of economic activity and the prospects for the development of the country's economy as a whole. It is the basis for making economically sensible decisions about the effectiveness of identifying and using resources, and analyzes business cycles. This index is associated with the concept of economic cycles, because the economy develops unevenly and in its dynamics can be traced to the presence of certain cycles. So on its basis it is possible to identify and predict the crisis phenomena that occur in the economy and to develop possible ways out of a difficult situation [2].

The purpose of this paper is to verify whether it is possible to use some of the economic indicators for calculating the business confidence index. Based on the selected methods we will try to confirm or reject the hypothesis which say that business confidence index can be predicted on the base of coincident indicators. The methodological basis for choosing economic indicators is the recommendations for calculating the business expectations indicators set out in the Joint Harmonised EU Programme of Business and Consumer Surveys, which contains the clear definition of the list of business expectations indicators and the methodology for their calculation [3].

Confidence indicators reflect entrepreneurs' perceptions and expectations at the sector level in the one-dimensional index. They are calculated as the simple arithmetic average of the balances of answers (in percentage points) to selected questions [4]. The respondents are asked to give their assessments of the current business situation and their expectations for the next six or twelve months. The situation can be characterised as "good", "satisfactorily" or "poor". The business expectations of the respondents for the next period are characterised as "more favourable", "unchanged" or "more unfavourable". The balance value of the current business situation is the difference of the percentages of the responses "good" and "poor", the balance value of the expectations is the difference of the responses "more favourable" and "more unfavourable" percentages. The business confidence index is a mean of the balances of the business situation and the expectations.

Ukrainian business confidence index is calculated since 2006 and consists of five averages of the balances in the industry, construction, retail and wholesale trade, agriculture, transport and some others (Figure 1).

According to the method of the Organisation for Economic Co-operation and Development (OECD)

* Corresponding author: vitalos.2704@gmail.com 
composite confidence indicator (business confidence index) is average of the industrial confidence indicator (ICI), construction confidence indicator $(\mathrm{CCI})$, retail trade confidence indicator (RCI) and confidence indicator for services (SCI) [5]. The industrial confidence indicator is an average of the balances to the questions in the industry survey relating to future tendency of production, total order books, stocks of finished goods. The construction confidence indicator is an average of the balances to the questions in the construction relating to total order books and future tendency of employment.

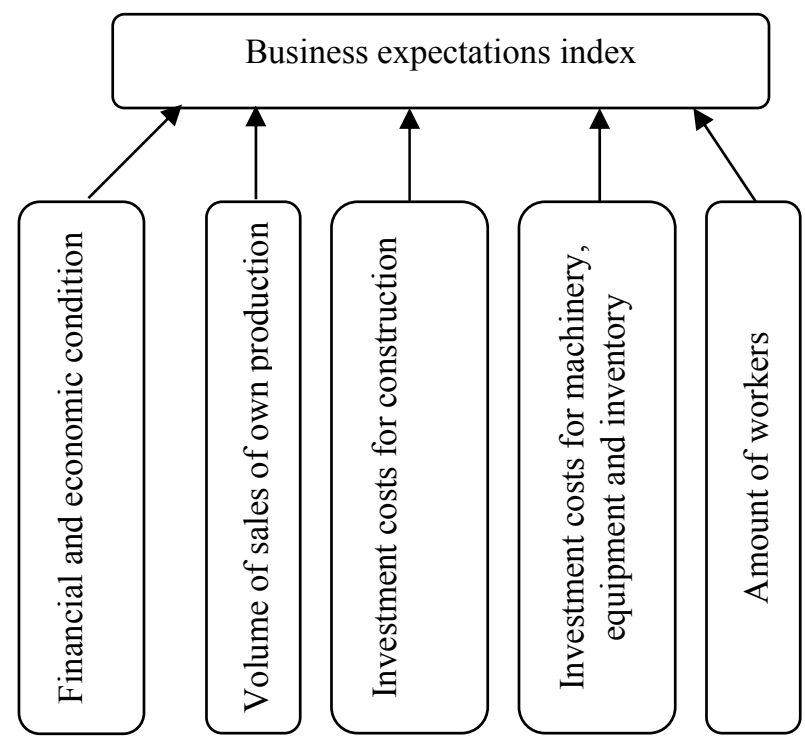

Fig. 1. The balances of business confidence index in Ukraine.

The retail trade confidence indicator is an average of the balances to the questions in the retail trade survey relating to present business situation, future tendency of the business situation and stocks. The confidence indicator for services is an average of the balances to the questions in the survey relating to the future tendency of employment, present business situation, future tendency of business situation.

\section{Construction and forecast of business confidence index}

Cross-correlation is a standard method of estimating the correlation degree of sequences [6]. The correlation coefficient $r$ between the business confidence index $\left(x_{i}\right)$ and economic indicator $\left(y_{i}\right)$ with time delay $t$, where $i=1,2, \ldots, N$ is considered. Time delay $t$ and length of correlation series could be less than $N$, e.g., goal may be the verification of correlation for the limited set of measurements. Coefficient $r=1$ lies in the range of $-1 \leq r \leq 1$ and the boundary values of this range point out to maximum correlation. When $r=0$, correlation is absent. For the case of correlation coefficient equal to unity, there is a coincidence of the series and, accordingly, the maximum degree of correlation. When correlation coefficient is close to the unity in absolute value, but has a negative value, there is an inverse correlation, i.e., it is a contrary relationship between two variables such that they move in opposite directions.

In order to verify if a given economic indicator shown sufficient concurrence with business confidence index and does not behave as e.g. leading or lagging indicator, we will apply cross correlations for 12 periods forward and backwards. The first condition for including economic indicators in the groups of leading, coincident or lagging indicators is the highest absolute value of correlation coefficient must be at least 0,55 [7]. The second condition for including economic indicators contains the following:

1. coincident indicators have the highest absolute value of correlation coefficient in the period of time $t$;

2. lagging indicators have the highest absolute value of correlation coefficient is on the right side from $t$;

3. leading indicators have the highest absolute value of correlation coefficient is on the left side from $t$.

We have chosen the secondary data for our analysis, obtained from the National Bank of Ukraine [8], OECD [9] and CESifo Group Munich [10]. In all cases it was times series with quarterly periodicity.

To calculate the index of business expectations, we use the time series of economic indicators that correspond to the components of the index of business expectations. Based on the International System of Leading Indicators in the part of business tendency survey for analysis the following indicators were chosen: producer prices (index points), unemployment rate ( $\%$ of labour force), Gross Domestic Product (annual growth rate), new orders (index points). The indicators used for the countries have been analyzed and time series are listed in Table 1.

Table 1. Economic indicators used for the analysis of business confidence index according to countries [11-15].

\begin{tabular}{|c|c|c|}
\hline Countries & $\begin{array}{l}\text { Time series } \\
\text { (quarterly) }\end{array}$ & Economic indicators \\
\hline Ukraine & $2007-2018$ & - producer prices (index points) \\
\hline Slovenia & $2000-2018$ & $\begin{array}{l}\text { - unemployment rate }(\% \text { of } \\
\text { labour force), } \\
\text { - Gross Domestic } \\
\text { (annual growth rate) }\end{array}$ \\
\hline Germany & $2005-2018$ & \\
\hline Hungary & $2001-2018$ & \multirow{2}{*}{$\begin{array}{l}\text { - unemployment rate }(\% \text { of } \\
\text { labour force), } \\
\text { - Gross Domestic Product } \\
\text { (annual growth rate), } \\
\text { - new orders (index points) }\end{array}$} \\
\hline Poland & $2006-2018$ & \\
\hline
\end{tabular}

After the application of the selected methods, we got the result of cross correlations for all selected economic indicators for each country. Based on the results, we are able to assess, which indicators behave in line with the business confidence index and which act with a delay or in advance as compared to the business confidence and expectations.

Concerning Ukraine, we have the time series of the selected economic indicators and analyzed their in relation to business confidence index through cross 
correlations. The results of these correlations are compared in Table 2.

The results of these correlations, with the range of 12 quarters forwards and backwards show that only two economic indicators act with business confidence index of Ukraine. The maximum value of cross correlation between producer prices and business confidence index were achieved in the period of time $t-12$ and there absolute value were below 0,55 $(0,2119)$. It means that this indicator does not show any relationship with any Ukrainian business confidence expectations. The result of the cross correlation between unemployment rate and business confidence index was achieved in the period of time $t-1$ and there absolute values were above $0,55 \quad(0,721)$. Consequently, unemployment rate is the leading indicator for business confidence index of Ukraine. The Gross Domestic Product (annual growth rate) is coincident indicator with business confidence index, because the highest absolute value of correlation coefficient is in the period of time $t$ and its meaning 0,8657 . This economic indicator is a reflection of the financial and economic state of the country and is very important for the business community of each country.

Table 2. Result of cross correlation between the business confidence index and economic indicators in 2007-2018 of Ukraine.

\begin{tabular}{|c|c|c|}
\hline Economic indicators & Lag & $\begin{array}{l}\text { Maximal absolute value } \\
\text { of cross correlation }\end{array}$ \\
\hline $\begin{array}{l}\text { producer prices } \quad \text { (index } \\
\text { points) }\end{array}$ & $t-12$ & 0,2119 \\
\hline 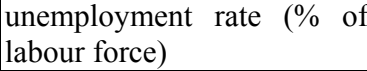 & $t-1$ & 0,721 \\
\hline $\begin{array}{l}\text { Gross Domestic Product } \\
\text { (annual growth rate) }\end{array}$ & $t$ & 0,8657 \\
\hline
\end{tabular}

We have also assessed the relation between the business confidence index and economic indicators of Germany. The results of these correlations are compared in Table 3.

Table 3. Result of cross correlation between the business confidence index and economic indicators in 2005-2018 of Germany.

\begin{tabular}{|l|c|c|}
\hline \multicolumn{1}{|c|}{ Economic indicators } & Lag & $\begin{array}{c}\text { Maximum absolute value } \\
\text { of cross correlation }\end{array}$ \\
\hline $\begin{array}{l}\text { producer prices (index } \\
\text { points) }\end{array}$ & $t-2$ & 0,4883 \\
\hline \begin{tabular}{l} 
unemployment rate $\left(\begin{array}{l}\% \\
\text { labour force) }\end{array}\right.$ \\
\hline $\begin{array}{l}\text { Gross Domestic Product } \\
\text { (annual growth rate) }\end{array}$
\end{tabular} & $t$ & 0,503 \\
\hline new orders (index points) & $t$ & 0,7685 \\
\hline
\end{tabular}

Cross correlations between producer prices and business confidence index and between unemployment rate and business confidence index do not show any relationship insofar as there maximum absolute value were below $0,55(0,4883$ and 0,503 respectively).

But, in the case of Germany we have found that 2 out of 4 tracked indicators report the maximum values of cross correlations above the level of 0,75 showing strong relationship of these indicators with the business confidence index. Such indicators are Gross Domestic Product and new orders. These indicators are coincident with the highest value of correlation coefficients in the period of time $t(0,7685$ and 0,907 respectively). We can recommend these indicators as an alternative to business confidence index, when it comes to monitoring economic tendency of Germany.

The next country for analysis is Hungary. The results of correlations for this country are compared in Table 4.

Table 4. Result of cross correlation between the business confidence index and economic indicators in 2001-2018 of Hungary.

\begin{tabular}{|l|c|c|}
\hline \multicolumn{1}{|c|}{ Economic indicators } & Lag & $\begin{array}{c}\text { Maximum absolute value } \\
\text { of cross correlation }\end{array}$ \\
\hline $\begin{array}{l}\text { producer prices (index } \\
\text { points) }\end{array}$ & $t+4$ & 0,360 \\
\hline $\begin{array}{l}\text { unemployment rate (\% of } \\
\text { labour force) }\end{array}$ & $t-2$ & 0,476 \\
\hline $\begin{array}{l}\text { Gross Domestic Product } \\
\text { (annual growth rate) }\end{array}$ & $t$ & 0,6181 \\
\hline new orders (index points) & $t+1$ & 0,4297 \\
\hline
\end{tabular}

Cross-correlation analysis revealed that three economic indicators do not affect the business confidence index of Hungary. The absolute value correlations of these economic indicators with business confidence index are below the threshold value of 0,55 . They are equal $0,360,0,476,0,4297$ for producer prices, unemployment rate and new orders respectively. Only Gross Domestic Product is coincidental indicator with business confidence index; maximum absolute value of cross correlation is equal 0,6181 .

We have also assessed the relation between the economic indicators and business confidence index of Slovenia. The results of these correlations are compared in Table 5.

Table 5. Result of cross correlation between the business confidence index and economic indicators in 2000-2018 of Slovenia.

\begin{tabular}{|l|c|c|}
\hline \multicolumn{1}{|c|}{ Economic indicators } & Lag & $\begin{array}{c}\text { Maximum absolute value } \\
\text { of cross correlation }\end{array}$ \\
\hline $\begin{array}{l}\text { producer prices (index } \\
\text { points) }\end{array}$ & $t+12$ & 0,1644 \\
\hline $\begin{array}{l}\text { unemployment rate (\% of } \\
\text { labour force) }\end{array}$ & $t-6$ & 0,415 \\
\hline $\begin{array}{l}\text { Gross Domestic Product } \\
\text { (annual growth rate) }\end{array}$ & $t-1$ & 0,8425 \\
\hline
\end{tabular}

Such economic indicators as producer price and unemployment rate are characterized by lack of relations with business confidence index of Slovenia. There maximum absolute value of cross correlations are 0,1644 and 0,415 respectively. The Gross Domestic Product is leading indicator of business confidence index with a lead of 1 quarter and maximum absolute value of cross correlation 0,8425 . 
The last monitored economy is Poland. The results of correlations for this country are compared in Table 6.

Cross-correlation analysis revealed that two economic indicators do not affect the business confidence index of Poland. Such indicators as producer prices and unemployment rate have a maximum absolute value of cross correlation less than the threshold value ( 0,4894 and 0,435 respectively). The maximum absolute value of cross correlation between new orders and business confidence index is above the threshold value $(0,7012)$, but this indicator is lagging with period of time $t+1$. Therefore, this indicator is excluded from further consideration. The Gross Domestic Product is coincident indicator with the business confidence index with high level of correlation $(0,8794)$.

Table 6. Result of cross correlation between the business confidence index and economic indicators in 2006-2018 of Poland.

\begin{tabular}{|l|c|c|}
\hline Economic indicators & Lag & $\begin{array}{c}\text { Maximum absolute value } \\
\text { of cross correlation }\end{array}$ \\
\hline $\begin{array}{l}\text { producer prices (index } \\
\text { points) }\end{array}$ & $t+12$ & 0,4894 \\
\hline $\begin{array}{l}\text { unemployment rate }(\% \text { of } \\
\text { labour force) }\end{array}$ & $t+11$ & 0,435 \\
\hline $\begin{array}{l}\text { Gross Domestic Product } \\
\text { (annual growth rate) }\end{array}$ & $t$ & 0,8794 \\
\hline new orders (index points) & $t+1$ & 0,7012 \\
\hline
\end{tabular}

The next step of business confidence index analysis is the construction regression model with coincident economic indicators and the forecast of the business confidence index for the next period. In order to forecast economic indicators for the next value in the next period of time it was used the single exponential smoothing with smoothing parameter $\alpha$ [16]. In this paper the smoothing parameter is $\alpha=0,9$.

Investigate the applicability of linear and nonlinear (multiplicative) regression models for forecast of the business confidence index. Linear regression models are easiest to calibrate and are the most common. Some nonlinear regression models can be transformed to a linear model by means of some transformation such as logarithmization of dependent and independent variables. Predicted values can then be converted to ordinary numbers by taking their antilog or exponential [17]. Economic indicators are represented by percentage changes or index values changes. But some values of Gross Domestic Product (annual gross indicator) take negative values. Since the logarithmic function for negative values is not defined, the use of multiplicative models for forecast of the business confidence index is impossible. Therefore, for further research we will use the linear regression model which allow use of absolute and relative indicators that take both positive and negative values.

For Ukraine time series of data consists of 47 quarterly values (1st quarter 2007 - 3rd quarter 2018). The regression model of business confidence index of Ukraine is

$$
\begin{aligned}
& B C I_{\text {Ukraine }}=136,892-2,729 \cdot U R_{\text {Ukraine }}+ \\
& +1,579 \cdot G D P_{\text {Ukraine }},
\end{aligned}
$$

where $B C I_{\text {Ukraine }}$ - business confidence index of Ukraine (index points);

$U R_{\text {Ukraine }}$ - Ukrainian unemployment rate (\% of labour force);

$G D P_{\text {Ukraine }}$ - Gross Domestic Product (annual growth rate) of Ukraine.

The model is qualitative $\left(R^{2}=0,882\right)$ and statistically significant $\left(F_{\text {cal }}=197,9>F_{\text {table }}=3,2\right.$ with 95\% confidence that there is no significant difference in precision). The mean absolute percentage error (MAPE) of predicted values is $1,4 \%$. Actual and predicted values of business confidence index of Ukraine is presented on Figure 2.

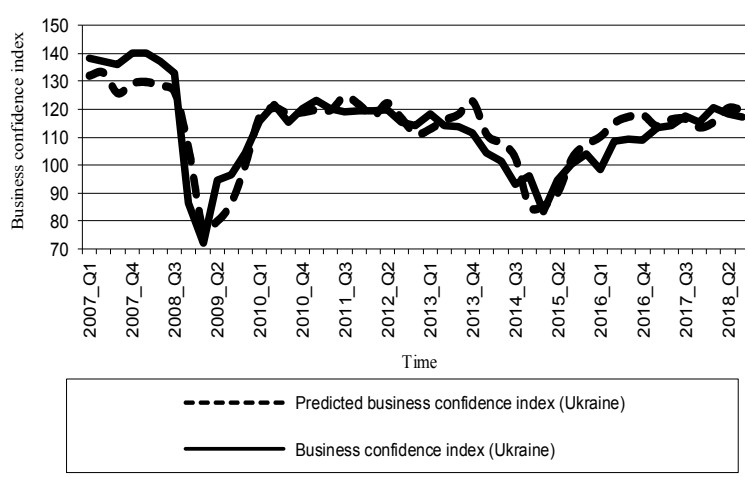

Fig. 2. Actual and predicted values of business confidence index in 2007-2018 of Ukraine.

The forecast value of the business confidence index for the 4th quarter of 2018 is 119,5 and is in confidence interval $[92,24 ; 146,77]$ with $95 \%$ confidence level. The forecast confirms the continued growth of business activity level in the economy of Ukraine.

For Germany time series of data consists of 56 quarterly values (the 1 st quarter 2005 - the 4 th quarter 2018). The regression model of business confidence index of Germany is

$$
\begin{aligned}
& B C I_{\text {Germany }}=57,33+0,69 \cdot G D P_{\text {Germany }}+ \\
& +0,41 \cdot N O_{\text {Germany }},
\end{aligned}
$$

where $B C I_{\text {Germany }}$ - business confidence index of Germany (index points);

$G D P_{\text {Germany }}$ - Gross Domestic Product (annual growth rate) of Germany;

$N O_{\text {Germany }}$ - new orders (index points) of Germany.

The model is qualitative $\left(R^{2}=0,787\right)$ and statistically significant $\left(F_{\text {cal }}=81,4>F_{\text {table }}=3,2\right.$ with $95 \%$ confidence that there is no significant difference in precision). The mean absolute percentage error (MAPE) of predicted values is 5,2\%. Actual and predicted values of business confidence index of Germany are presented on Figure 3.

The forecast value of the business confidence index for the 1st quarter of 2019 is 101,4 and is in confidence interval $[91,41 ; 111,41]$ with $95 \%$ confidence level. 
The forecast confirms the continuation of the fall in the level of business activity in the economy of Germany.

For the next country - Hungary - time series of data consists of 72 quarterly values (1st quarter 2001 4th quarter 2018). The regression model of business confidence index of Hungary is

$$
B C I_{\text {Hungary }}=99,19+0,31 \cdot G D P_{\text {Hungary }},
$$

where $B C I_{\text {Hungary }}$ - business confidence index of Hungary (index points);

$G D P_{\text {Hungary }}$ - Gross Domestic Product (annual growth rate) of Hungary.

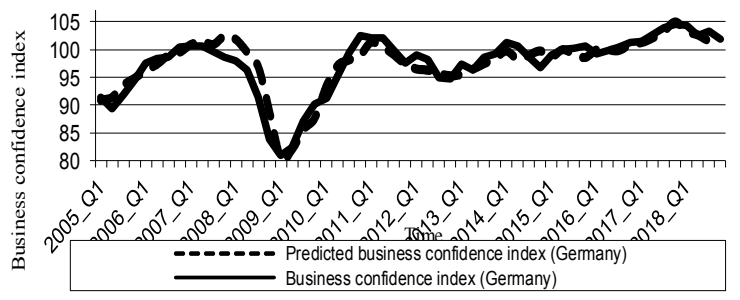

Fig. 3. Actual and predicted values of business confidence index in 2005-2018 of Germany.

For the constructed model, the approximation accuracy is insufficient $\left(R^{2}=0,382\right)$ and the model requires improvement. Actual values of business confidence index of Hungary are presented on Figure 4.

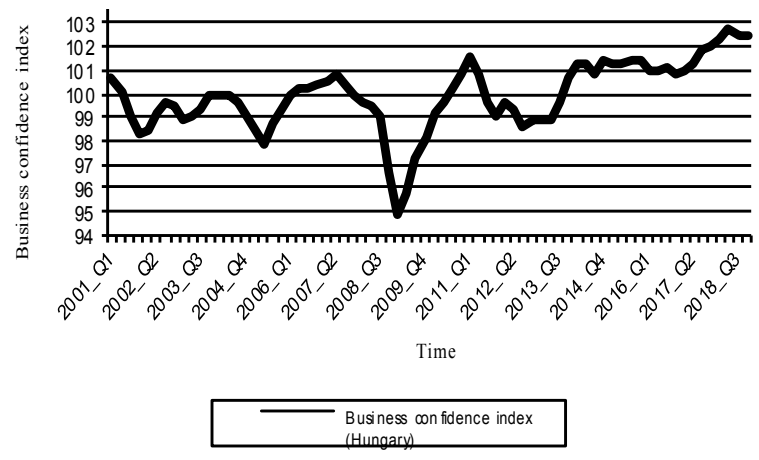

Fig. 4. Actual values of business confidence index in $2001-$ 2018 of Hungary.

For the construction of the index of business expectations in Hungary required an additional analysis of indicators, that affect the expectations of the business environment.

For Slovenia time series of data consists of 76 quarterly values (1st quarter 2000 - 4th quarter 2018). The regression model of business confidence index of Slovenia is

$$
B C I_{\text {Slovenia }}=99,123+0,474 \cdot G D P_{\text {Slovenia }},
$$

where $B C I_{\text {Slovenia }}$ - business confidence index of Slovenia (index points);

$G D P_{\text {Slovenia }}$ - Gross Domestic Product (annual growth rate) of Slovenia.

The model is qualitative $\left(R^{2}=0,701\right)$ and statistically $\quad$ significant $\quad\left(F_{\text {cal }}=173,4>F_{\text {table }}=3,97\right.$ with $95 \%$ confidence that there is no significant difference in precision). The mean absolute percentage error (MAPE) of predicted values is $0,9 \%$. Actual and predicted values of business confidence index of Slovenia presented on Figure 5.

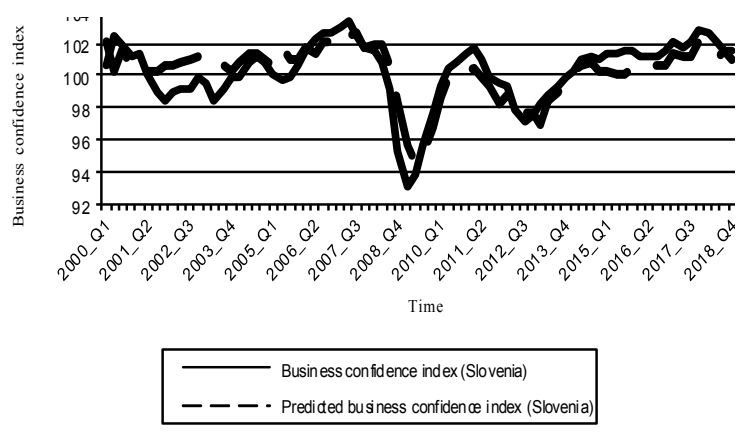

Fig. 5. Actual and predicted values of business confidence index in $2000-2018$ of Slovenia.

The forecast value of the business confidence index for the 1st quarter of 2019 is 101,1 and is in confidence interval $[97,78 ; 104,43]$ with $95 \%$ confidence level. The forecast confirms the continuation of the fall in the level of business activity in the economy of Slovenia.

For Poland time series of data consists of 52 quarterly values (the 1st quarter 2006 - the 4th quarter 2018).The regression model of business confidence index of Poland is

$$
B C I_{\text {Poland }}=98,283+0,486 \cdot G D P_{\text {Poland }},
$$

where $B C I_{\text {Poland }}$ - business confidence index of Poland (index points);

$G D P_{\text {Poland }}$ - Gross Domestic Product (annual growth rate) of Poland.

The model is qualitative $\left(R^{2}=0,773\right)$ and statistically significant $\quad\left(F_{\text {cal }}=170,7>F_{\text {table }}=4,03\right.$ with $95 \%$ confidence that there is no significant difference in precision). The mean absolute percentage error (MAPE) of predicted values is $0,38 \%$. Actual and predicted values of business confidence index of Poland are presented on Figure 6.

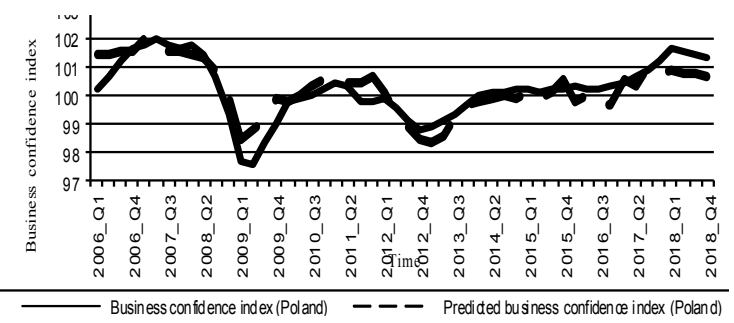

Fig. 6. Actual and predicted values of business confidence index of Poland in $2006-2018$.

The forecast value of the business confidence index for the 1st quarter of 2019 is 100,7 and is in confidence interval $[98,88 ; 102,48]$ with $95 \%$ confidence level. The forecast confirms the continuation of the fall in the level of business activity in the economy of Poland. 


\section{Conclusions}

As mentioned above, generalized business confidence index is determined on the basis of the survey of respondents in a country regarding their business expectations. This assessment process is quite costly and problematic, as business entities may be more optimistic in their expectations during the survey. This, in turn, will lead to inaccurate information. Thus, the existing approach of determining the business confidence index is imperfect and requires clarification by formalizing the evaluation process. It can be carried out by means of the selection and justification of quantitative socio-economic indicators, on the basis of which the business confidence index will be determined. One more important condition is that the indicators belong to the group of leading, which would allow to establish and recognize crisis phenomena in the economy.

Finally, the business confidence index was improved, based on a system of socio-economic factors. The absolute value of correlation coefficient the indicators with the business confidence index must be the high. Also the indicators were grouped into three groups, and indicators that belonged to the group of coincident and the group of leading were chosen for estimation and forecasting.

The result of prediction of the business confidence index of Ukraine in the 4th quarter of 2018 will be equal to 119,5 and will increase by 1,97 percent from the 3rd quarter of 2018. This confirms the continuing optimism of respondents in Ukraine.

Predicted results for Germany, Slovenia an Poland show that the business confidence index for these countries in the 1th quarter of 2019 will be decrease from the 4th quarter of 2018 by $0,57,0,43$ and 0,64 percent respectively. This is due to the uncertainty of business expectations in these countries.

For the prediction of the index of business expectations in Hungary the additional analysis is required. The results of cross-correlation and regression analyzes showed that Gross Domestic Product (annual growth rate) is not the main factor that influences business expectations in this country.

\section{References}

1. Gagea, M.: Confidence indicators analysis in the context of Romanian and European economy. Procedia Soc Behav Sci. 62, 393-397 (2012)

2. Pronoza, P.: Theory and practice of early recognition of crisis processes in economy. Innovatsiina ekonomika. 51, 198-209 (2014)

3. European Commission: The Joint Harmonised EU Programme of Business and Consumer Surveys: User Guide. http://ec.europa.eu/economy_finance/db_indicator s/surveys/documents/bcs_user_guide_en.pdf (2016). Accessed 21 Mar 2019
4. CESifo Group Munich: Calculating the ifo Business Climate. http://www.cesifogroup.de/w/45YCTv5Bp (2019). Accessed 18 Feb 2019

5. OECD: Business Tendency Surveys: A Handbook. http://www.oecd.org/sdd/leadingindicators/31837055.pdf (2003). Accessed 21 Mar 2019

6. Bourke, P: Cross Correlation. http://paulbourke.net/miscellaneous/correlate (1996). Accessed 20 Feb 2019

7. Bilan, Y, Gavurova, B., Gedek, S., Tkacova, A.: The Composite Coincident Indicator (CCI) for business cycles. Acta Polytechnica Hungarica. 7(14), 71-90 (2017). doi:10.12700/APH.14.7.2017.7.5

8. National bank of Ukraine: Business expectations of https://bank.gov.ua/control/uk/publish/ enterprises. category?cat_id=58374 (2019). Accessed 18 Feb 2019

9. OECD Data: Leading indicators - Business Confidence Index (BCI). https://data.oecd.org/leadind/ business-confidenceindex-bci.htm (2019). Accessed 18 Feb 2019

10. CESifo Group Munich: Long time-series for the ifo Business Climate. http://www.cesifogroup.de/w/AABWVtCn (2019). Accessed 18 Feb 2019

11. Tradingeconomics.com: Producer prices. https://tradingeconomics.com/countrylist/producer-prices (2019). Accessed 18 Feb 2019

12. Unemployment - Unemployment rate. OECD Data. https://data.oecd.org/unemp/unemploymentrate.htm (2019). Accessed 18 Feb 2019

13. Tradingeconomics.com: Ukraine Unemployment Rate. https://tradingeconomics.com/ukraine/ unemployment-rate (2019). Accessed 18 Feb 2019

14. Tradingeconomics.com: GDP annual growth rate. https://tradingeconomics.com/country-list/gdpannual-growth-rate (2019). Accessed 18 Feb 2019

15. Tradingeconomics.com: New orders. https://tradingeconomics.com/country-list/neworders (2019). Accessed 18 Feb 2019

16. Hyndman, R.J., Athanasopoulos, G.: Forecasting: principles and practice. OTexts, Melbourne (2013)

17. Gloudemans, R.J.: Comparison of three residential regression models: Additive, multiplicative, and nonlinear. Assessment Journal: 9(4), 25-36 (2002) 